drainage by the fall of the gateway before assault and conflagration, afforded the first tangible archæological evidence differentiating the two Babylonian attacks of 597 B.c. and 588 B.C., hitherto not clearly to be distinguished. Tunnels cut in the contents of the great shaft-water-borne deposits, overlying the stones of the collapsed walls of the Jewish city-have as yet afforded no evidence of exits or means of access, nor can the purpose of the shaft yet be determined. Work on this rock-cut shaft, it can be seen, was still incomplete, when it was abandoned, possibly as a result of frontier troubles before the fall of the Jewish kingdom.

A Noteworthy feature among the exhibits is the collection of scarabs, which with the character of the amulets found at Tell Duweir in Sixth and Seventh Century tomb-groups illustrate the persistent influence of Egyptian beliefs and ways of thought among the peoples of southern Palestine. In one of the numerous rock tombs of the north-east corner of the Tell nearly two hundred searabs of the Eighteenth and Nineteenth Dynasties were found. A continuous series of scarabs with the Royal name now covers the whole period of Egyptian occupation, with the exception of a gap of some fifteen years under Akhenaten and Tutankhamen. One of the most interesting objects in the exhibition, however, is a copper dagger, found in the excavations of 1934, but recently cleaned by the Palestine Museum of Antiquities and on loan by the Palestine Govern. ment. It belongs to the Hykos period and is certainly not later than 1600 B.C. Its interest lies in the fact that it is now seen to bear on one side characters in a pictographic script, affording proof of the development of a script independently of both Egypt and Mesopotamia. With the evidence of these pictographs of the now famous inscribed ewers and of the no less remarkable Lachish letters of the preexilic period, of which a detailed study by Dr. Harry Torezyner is now in the press, it is now possible to piece together something of the history of the development of writing in Palestine. The exhibition will remain open until August 7, a cinematograph film of the work of the expedition being shown twice daily; and on July 16 at 5.30, and July 28 at 6 p.m. lectures on the new discoveries will be delivered by Mr. Starkey at the Wellcome Research Institution.

\section{Gold Mining with the Aid of Aeroplanes}

Messrs Fraser and Chalmers, of Erith, Kent, have recently equipped a gold mine at Progresso in Peru, which is at a height of 12,800 feet above sealevel in an almost inaccessible district about ninety miles south-west of the city of Cuzco. A description of this mine and of some of the difficulties that had to be overcome in transporting the whole of the mine equipment, weighing 150 tons, and the buildings, weighing about 1,000 tons, to the site of the mine is given in the G.E.C. Journal (General Electric Co.) for May by W. Bullock. A railway line runs to within about seventy miles of the mine; the connexion between them is a mountain track, which can only be traversed by mules and llamas, and the journey takes fourteen days to complete. As the track over the mountains is often merely a narrow ledge on the side of a steep hill, it is impossible to carry by animals pieces of machinery or equipment more than 10 feet long. Sectionalizing the plant to this extent rendered this mode of transport impracticable. The engineers therefore chartered and equipped two aeroplanes, each capable of carrying a load of two tons. In this way it was found possible to transport reasonable loads by air. The actual time taken by air was about one hour and that taken by a llama was 14 days. The cost of the latter method, if it had been practicable, would have been one third the cost of transport by air. The ore, after being mined, is reduced in a 'breaker' and brought into the mill on a belt conveyor. It is crushed to pieces of about 2 in. cube size and distributed into a 450-ton crushed ore bin situated behind the stamp mill, which is provided with 24 stamps each having a falling weight of $2,100 \mathrm{lb}$.

\section{Pollution of Sea and Shore by Oil}

For several years, persistent complaints have been made about the damage caused to organisms upon the sea-shore and particularly to birds which frequent the surface by oil discharged from ships. The number of birds whose feathers become so coated with the discharge that they are unable to fly or to dive for food, and in consequence die a slow death from starvation, has been reported to be very great in some years and in some places. From preliminary investigations into the whole subject of oil pollution at sea, Prof. N. K. Adam has written a report, submitted to the Council of the Royal Society, and printed for private circulation, the general effect of which is to allay some of the fears aroused by the earlier records and surmises. In the seas about the British Isles, the principal sources of oil are wrecks, fuel oil accidentally discharged, usually from ballast tanks, and sludge from the cleaning of oil tanks on tankers or oil-burning ships. But the nuisance due to the oil appears to have diminished in recent years, owing partly to the regulations which now prohibit the discharge of oil or oily water near the coast, and partly to the increased use of separators on board ships. A reassuring statement is that fuel oil entirely loses its tendency to spread after a few weeks at ordinary temperatures on a water surface in contact with gravel. On the surface of the sea also it seems to disappear, for it is rare to see an oily film, and it has been found that no appreciable amount is present as an invisible film.

As regards damage caused by oil to marine plant and animal life, the evidence is inadequate and often contradictory. Prof. Adam's impression is that the moderate amount of pollution round our coasts appears to be doing little damage to life, other than birds, either between tide-marks or below low tide level; and that in other places, if there is very heavy and continuous oil pollution, life between tidemarks is seriously affected, but there is not much 
evidence of damage below low tide. The impression of the present writer, however, for what it is worth, is that in a limited area where pollution may be high, animals not exposed between tide-marks suffer and may be exterminated, and the supposition was that even if adult sessile forms may be able to withstand pollution, the delicate free-swimming ciliated larvæ, by which most sessile forms propagate, succumbed, and multiplication accordingly ceased. But that and several other matters referred to in the report await the test of experiment.

\section{Economic Value of an Experiment in Transplanting}

For some seventy years before 1917, the State of Pennsylvania possessed no beavers, and in that year two, imported from Wisconsin, were set free. Between 1917 and $-1924,94$ beavers were imported and liberated at a cost of about 50 dollars each. So rapidly did the creatures multiply that it soon became necessary to transfer some to other parts of the State.' A survey by the Board of Game Commissioners gives an idea of what the increase meant: in 1931 there were 899 beaver dams with an estimated population of 4,377 ; in 1934 , the population had risen to 15,000 . During the trapping season of 1934 the number of beavers taken was 6,455 , and the pelts brought the trappers a sum total of 22,610 dollars. Wherever beavers are doing damage, as in farming communities or in irrigation areas, the policy of the U.S. Bureau of Biological Survey has been to encourage and aid in the transference of the animals to carefully selected sites where their dam building may aid in the cause of conservation. To further this policy, the Bureau has published a Farmers Bulletin (No. 1768) on "Trapping and Transplanting Live Beavers", in which live-beaver traps are described and trapping methods and transport are discussed for the help of farmers, stockmen, foresters and others interested in beaver control.

\section{An Air-Conditioning Unit}

AN air-conditioning unit is usually a small cabinet, the only external evidence of its purpose being two small grilles. In Engineering of July 9, a description is given of one meant to stand on the room floor and placed near a window as the air inlet can then be readily arranged. It is about $40 \mathrm{in}$. high, $30 \mathrm{in}$. wide and $18 \mathrm{in}$. deep. It is electrically operated, and the supply cable can be plugged into any existing power point such as one used for a radio cabinet. With the air-cooled type this is all that is required, but with the water-cooled type connexions are needed with the water supply. In both summer and winter, the incoming air is first filtered; the inlet is a permanent fixture and does not interfere with opening the window for eleaning. Otherwise the window is kept closed to keep out the noise of street traffic. The fan is driven by a motor independent of the fans used for cooling and so can provide ventilation without either heating or cooling, if the outside air is in the desired condition. The cooling of the air and the removal of excess moisture by condensation is effected by a special refrigerator. The condensate is then re-evaporated and carried outside, so no drainpipe is required in the air-cooled unit. For increasing the moisture in the air, the water in the humidifier tank is vaporized by an electric immersion heater. The relative humidity is settled by a hygrostat which automatically controls the heater. A small neon light indicates when the heating elements are working, and reminds the occupant to consider whether it is advisable to turn off the heat at night when leaving the conditioning plant running.

\section{Atmospheric Pollution}

THE twenty-second report on atmospheric pollution contains an account of observations for the year ending March 31, 1936 (London : H.M. Stationery Office, 1937. 6s. net). Reviewing the last twenty years, it is concluded that the effort and propaganda of the period have brought about an appreciable reduction in air contamination. This now seems to have ceased, or even changed to a slight rise, probably on account of the increased industrial activity. Again the figures for some London stations are very high, especially for sulphur. Westminster shows some of the highest figures, and compares very unfavourably with some of the industrial areas. In some cases, remarkable improvements have been rendered over a period of years, and the causes deserve scrutiny. The report is cautious in its interpretation, as the difficulty of sampling is obvious. At Burnley a fifty per cent fall has been recorded in ten years - attributed to the removal of a factory. Attention is directed to the high drop at Wakefield in total deposit, from 613 tons per square mile in 1924 to 227 tons in 1935 . This may be associated with the persistent efforts made by the authorities there, and shows what is possible when those who wield political power treat seriously the problem of cleaner air. Unfortunately, it is only too rare that in local authorities the will and wish to improve the atmosphere are combined. The most important development recorded is the initiation of an intensive survey in and around Leicester-selected because it is relatively isolated from other industrial areas likely to prove disturbing factors.

\section{Empire Conference on Tuberculosis}

ThE Minister of Health, Sir Kingsley Wood, delivered the inaugural address on May 3 at the Empire Conference on the "Care and After-care of the Tuberculous" at Overseas House, St. James's, London. $\mathrm{He}$ first reviewed tuberculosis as a cause of mortality in England and Wales. The standardized death-rate from this disease has fallen from 3,638 per million of population in 1851-55 to 687 in 1935; nevertheless, tuberculosis in this country still comes next to cancer in the list of killing diseases. Sir Kingsley next dealt with the public provision for the treatment of tuberculosis - 29,000 beds in approved institutions -and the amount of expenditure thereon. $\mathrm{He}$ commended particularly the value of village settlements for treatment and after-care, and emphasized the importance of the after-care of patients who did not enter a village settlement. 